\title{
Lhermitte-Duclos Disease Treated Surgically in an Elderly Patient: Case Report and Literature Review
}

\author{
Yaşl Bir Hastada Cerrahi Yolla Tedavi Edilmiş Lhermitte-Duclos \\ Hastalığı: Olgu Sunumu ve Literatürün Gözden Geçirilmesi
}

Hiroaki MATSUMOTO, Hiroaki MINAMI, Yasuhisa YOSHIDA

Eisyokai Yoshida Hospital, Department of Neurosurgery, Kobe, Japan

Corresponding Author: Hiroaki MATSUMOTO / E-mail: hiroaki-matsu@umin.ac.jp

\begin{abstract}
A 75-year-old man with Lhermitte-Duclos Disease (LDD) manifesting as progressive headache is presented. Magnetic resonance imaging demonstrated a right cerebellar mass lesion with the characteristic "tiger-striped appearance". A mild mass effect was evident at the medulla oblongata, accompanied by inferior displacement of the right cerebellar tonsil. Thus, tonsillar herniation was considered the cause of his headache and he underwent partial resection of the tumor to solve tonsillar herniation. His headache gradually improved. LDD in the elderly is quite rare. Several differences in the nature of the lesion are seen in the elderly, with tendencies toward a male predominance, hypervascularity, and low rates of association with Cowden disease. Moreover, partial resection to reduce mass effect can improve clinical symptoms without recurrence. In symptomatic LDD in the elderly, to avoid surgical complication, we recommend partial resection to reduce mass effect.
\end{abstract}

KEYWORDS: Dysplastic gangliocytoma, Elderly patient, Headache, Lhermitte-Duclos Disease

öz

Yetmiş beş yaşında bir erkek hastada progresif baş ağrısı ile ortaya çıkan Lhermitte-Duclos Hastalığı (LDH) sunulmaktadır. Manyetik rezonans görüntüleme "Kaplan çizgileri" görünümü olan bir sağ serebellar kitle lezyonunu gösterdi. Medulla oblongata'da hafif bir kitle etkisi vardı ve sağ serebellar tonsil inferiora doğru yer değiştirmişti. Bundan dolayı tonsiller heniasyonun baş ağrısına neden olduğu düşünüldü ve hastaya tonsiller herniasyonun tedavisi için tümörün parsiyel rezeksiyonu uygulandı. Hastanın baş ağrısı tedrici olarak düzeldi. LDH yaşlılarda oldukça nadirdir. Bu hastalığın yaşlılarda görülen formunda tümörün natüründe bazı farklııklar vardır. Bunlar, erkek predominansı, hipervaskülarite ve Cowden hastalığı ile daha düşük oranda birlikteliktir. Ayrıca parsiyel rezeksiyon kitle etkisini azaltarak nüks olmadan klinik semptomların iyileşmesini sağlamıştır. Semptomatik LDH olan yaşlı hastalarda cerrahi komplikasyondan kaçınmak için kitle etkisini azaltmak amacıyla parsiyel rezeksiyon yapılmasını öneriyoruz.

ANAHTAR SÖZCÜKLER: Displastik gangliositoma, Yaşlı hasta, Baş ağrısı, Lhermitte-Duclos Hastalığı

\section{INTRODUCTION}

Lhermitte-Duclos Disease (LDD), also known as dysplastic gangliocytoma of the cerebellum, is a very rare pathological entity, characterized by a slowly progressive unilateral cerebellar mass lesion $(2,8)$. LDD occurs mainly in young adults of both sexes, and typically presents with headache, cerebellar dysfunction, occlusive hydrocephalus and cranial nerve palsies due to a progressive mass effect in the posterior fossa ( 2 , 8). LDD in the elderly is quite rare.

We describe herein a rare case involving an elderly patient with LDD and subsequently discuss the management of LDD in such patients.

\section{CASE REPORT}

A 75-year-old man presented with progressive headache, motor aphasia, and right hemiparesis without cerebellar symptoms. Computed tomography (CT) revealed a left-sided chronic subdural hematoma (CSDH) with midline shift and a low-density mass in the right cerebellar hemisphere (Figure 1A). The clinical symptoms were attributed to CSDH and treated surgically by one burr-hole craniostomy and closed drainage. Although motor aphasia and right hemiparesis improved postoperatively, headache remained. We therefore suspected that the cerebellar mass was causing the headache and performed additional investigations.

Magnetic resonance imaging (MRI) revealed a sharply defined mass in the right cerebellar hemisphere. The mass appeared hyperintense on diffusion-weighted imaging (Figure 1B), and hypointense on both fluid-attenuated inversion recovery imaging and T1-weighted imaging (Figures 1C, D). The characteristic "tiger-striped appearance" was visible on T2-weighted imaging (Figure 1F). Contrast-enhanced T1weighted imaging revealed subtle enhancement along the folia (Figure 1E). A mild mass effect was evident at the medulla oblongata, accompanied by inferior displacement of the right cerebellar tonsil. Moreover, the mass displayed high uptake of fluorodeoxyglucose (FDG) on FDG-positron emission 
tomography (PET)/CT (Figure 1G). Maximal standardized uptake volume (SUV) was 11 and tumor/normal brain uptake ratio ( $\mathrm{T} / \mathrm{N}$ ratio) was 1.6. Vertebral angiography showed slight tumor blush in the right cerebellar hemisphere (Figures $1 \mathrm{H}, \mathrm{I}$ ).

We considered that LDD with slight tonsillar herniation might be the cause of headache in this case. The mass was removed via a midline suboccipital approach with decompression of the foramen magnum and C1 laminectomy. Although the right cerebellar hemisphere was pale and enlarged with widened folia, margins to the mass lesion were not easily defined (Figure 2A). Partial resection of the mass to solve tonsillar herniation was thus performed, and subsequent histological examination confirmed the diagnosis of LDD. An enlarged molecular layer with dysplastic ganglion-like cells, hypertrophied granular layer, and increased numbers of small blood vessels within the molecular layer were detected by hematoxylin and eosin staining (Figures 2B-D). Dysplastic ganglion-like cells showed clear nuclear bodies and positive staining for synaptophysin (Figure $2 \mathrm{E}$ ). No mitotic cells were apparent, with an MIB-1 index of $<0.1 \%$.

The postoperative course was uneventful, and headache gradually improved. Follow-up MRI performed 2 years postoperatively showed no regrowth of the lesion and improved tonsillar herniation. Genetic testing for Cowden disease $(C D)$ yielded negative results.

\section{DISCUSSION}

LDD is a very rare, progressive pathological entity of unclear nature and pathogenesis $(2,8)$. More than 200 cases have been reported in the literature (3). Most cases documented have occurred in adults in the third and fourth decades of life, with no sex predilection $(2,8)$. LDD in the elderly is quite rare, with only 5 other cases reported in patients over 60 years old $(2,5-7,10)$. Table I summarizes the clinical features of LDD in the elderly, including the present case. Among these 6 patients, five were in the sixth decade of life and only
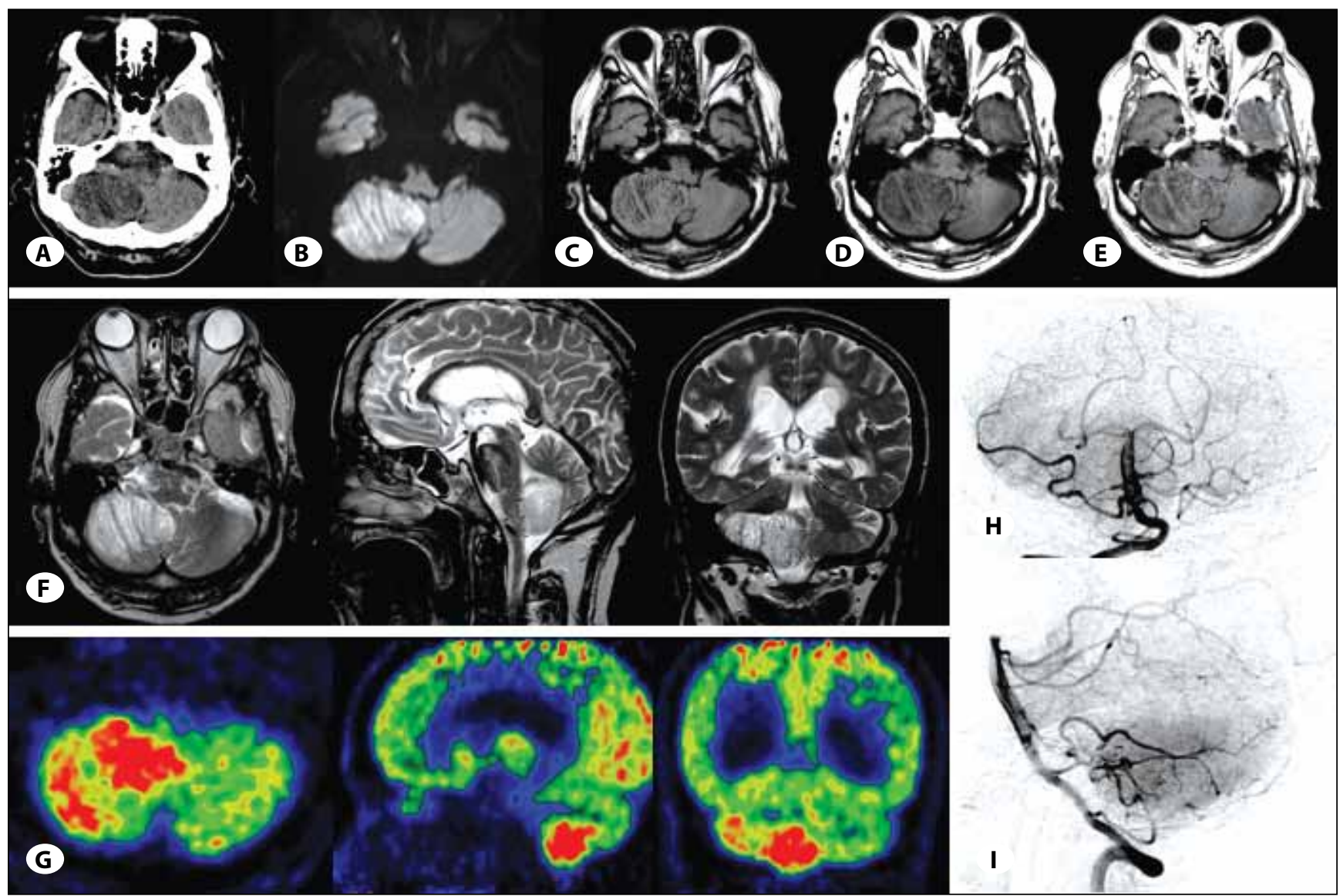

Figure 1: Preoperative investigations. A) Computed tomography showed a low-density mass without calcification in the right cerebellar hemisphere. B) Diffusion-weighted image demonstrated the tumor as a high intensity striped lesion. C) Fluid-attenuated inversion recovery image demonstrated the tumor as a low intensity striped lesion. D) T1-weighted image demonstrated the tumor as a low intensity striped lesion. E) Gadolinium-enhanced T1-weighted image demonstrated subtle enhancement along the folia. F) T2weighted image demonstrated the characteristic "tiger-striped appearance" of the lesion that is a typical finding in Lhermitte- Duclos disease. A mild mass effect was evident at the medulla oblongata, accompanied by inferior displacement of the right cerebellar tonsil. G) A FDG-PET image showed increased FDG uptake within the right cerebellar lesion. $\mathbf{H}$ and I) Vertebral angiography showed slight tumor blush in the right cerebellar hemisphere (H: anteroposterior view, I: lateral view). 
1 was in the seventh. These patients were predominantly male ( 5 males, 1 female). All patients were symptomatic; headache and cerebellar sign were general symptoms. All patients underwent partial resection and one patient added ventriculoperitoneal shunt because of occlusive hydrocephalus.

LDD may occur either as a sporadic, isolated disease or in association with $\mathrm{CD}$, an autosomal-dominant multiple hamartoma syndrome. It is sometimes accompanied by malignant tumors, including thyroid carcinoma, breast carcinoma, endometrial carcinoma, prostate carcinoma and glioblastoma $(2,8)$. Approximately half of LDD cases are associated with CD (7). Careful systemic investigation for CD should thereby be performed in LDD patients (7). In the present case, genetic testing for CD yielded negative results and sporadic isolated LDD was diagnosed. Among the 6 reported cases in elderly individuals, only one was associated with $C D$. Although there is a tendency for LDD in the elderly to be the sporadic isolated type, investigation for $C D$ remains prudent.

LDD has been proven to show a characteristic appearance on neuroimaging. CT usually reveals a low-density mass in the lesion and calcification is sometimes present $(2,6,8)$. MRI shows the lesion better than $C T$, with a characteristic striated
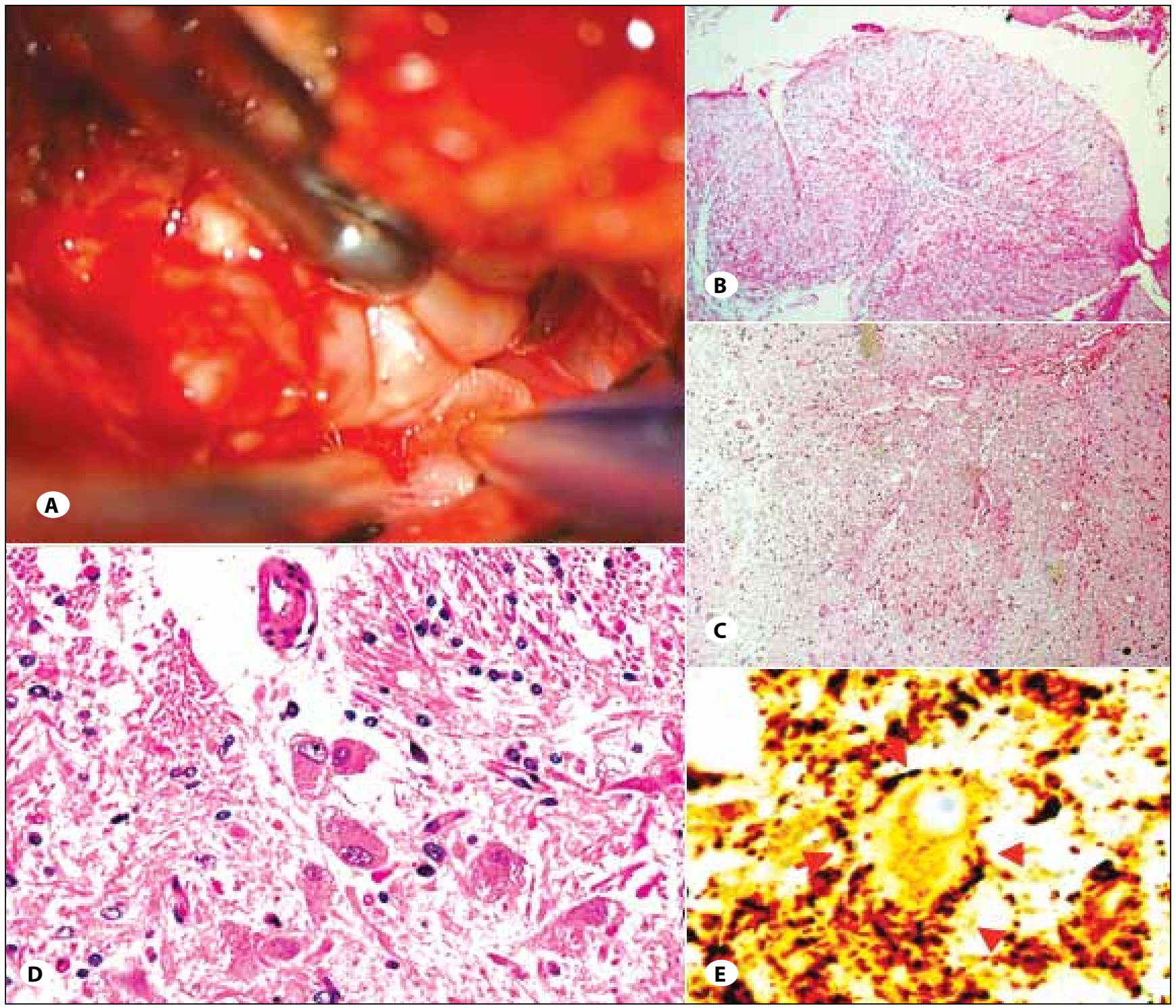

Figure 2: A) Intraoperative photograph showed that the right cerebellar hemisphere was pale and enlarged with widened folia. B-E) Microscopic examination of the tumor specimen. Photomicrograph showed an enlarged molecular layer (B: hematoxylin and eosin stain $[H \& E], \times 40)$. Photomicrograph showed increase numbers of small blood vessels within the molecular layer (C: $H$ \& $E, \times 100)$. Abnormal ganglion-like neurons showed eosinophilic cytoplasm and large nuclei $(\mathrm{E}: \mathrm{H} \& \mathrm{E}, \times 200)$. Dysplastic ganglion cell was positive for synaptophysin (D: × 400). 
Table I: Summary of Reported Cases of LDD in the Elderly

\begin{tabular}{|c|c|c|c|c|c|c|c|c|c|}
\hline $\begin{array}{l}\text { Author } \\
\text { (years) }\end{array}$ & $\begin{array}{c}\text { Age } \\
\text { (years) }\end{array}$ & $\begin{array}{l}\text { Sex } \\
(\mathrm{M} / \mathrm{F})\end{array}$ & $\begin{array}{c}\text { Clinical } \\
\text { symptoms }\end{array}$ & $\begin{array}{l}\text { Special findings } \\
\text { in neuro-images }\end{array}$ & $\begin{array}{l}\text { Surgical } \\
\text { treatment }\end{array}$ & $\begin{array}{c}\text { Outcome } \\
\text { (GOS) }\end{array}$ & Recurrence & $\begin{array}{l}\text { Follow } \\
\text { up } \\
\text { (mos) }\end{array}$ & $\begin{array}{l}\text { Association } \\
\text { with CD }\end{array}$ \\
\hline $\begin{array}{l}\text { Ishizaki } \\
\text { et al. (1997) }\end{array}$ & 61 & M & $\begin{array}{c}\text { ataxia gait } \\
\text { memory } \\
\text { disturbance }\end{array}$ & $\begin{array}{l}\text { enhancement } \\
\text { on MRI } \\
\text { tumor stain } \\
\text { on AG }\end{array}$ & PR & GR & ND & ND & none \\
\hline $\begin{array}{l}\text { Moonis } \\
\text { et al. (2004) }\end{array}$ & 60 & M & $\begin{array}{l}\text { headache } \\
\text { dizziness }\end{array}$ & none & PR & GR & ND & ND & yes \\
\hline $\begin{array}{l}\text { Nakagawa } \\
\text { et al. (2007) }\end{array}$ & 67 & $M$ & unconsciousness & none & PR & GR & none & 11 & none \\
\hline $\begin{array}{l}\text { Andres } \\
\text { et al. (2009) }\end{array}$ & 61 & M & $\begin{array}{l}\text { headache } \\
\text { ataxic gait }\end{array}$ & $\begin{array}{l}\text { tumor stain } \\
\text { on } A G\end{array}$ & PR & GR & none & 36 & none \\
\hline $\begin{array}{l}\text { Yang et al. } \\
(2012)\end{array}$ & 68 & $\mathrm{~F}$ & vertigo & $\begin{array}{c}\text { enhancement } \\
\text { on MRI }\end{array}$ & $\begin{array}{l}\text { PR+V-P } \\
\text { shunt }\end{array}$ & GR & none & ND & none \\
\hline $\begin{array}{l}\text { Present } \\
\text { case }\end{array}$ & 75 & M & $\begin{array}{l}\text { headache tumor } \\
\text { stain on } A G\end{array}$ & $\begin{array}{c}\text { enhancement } \\
\text { on MRI }\end{array}$ & PR & GR & none & 24 & none \\
\hline
\end{tabular}

AG: angiography, CD: Cowden disease, GOS: Glasgow outcome scale, GR: good recovery, MRI: magnetic resonance imaging, ND: not described, PR: partial resection.

appearance of hyperintensity on T2-weighted imaging and hypointensity on T1-weighted imaging giving rise to a "tigerstriped" appearance $(2,6,8)$. Lack of enhancement is the rule for this tumor, except in rare cases $(2,5)$. Angiography shows LDD as an avascular mass (5). On FDG-PET, LDD displays high uptake of FDG, similar to malignant tumors $(2,3,7)$. The reason for this high uptake of FDG remains unclear, and may simply reflect focally increased cell density and/or changes in the metabolism of dysplastic ganglion cells (3).

In the present case, the characteristic feature of "tigerstriped appearance" and high uptake of FDG were visible on preoperative investigations. On the other hand, subtle enhancement along the folia on contrast-enhanced T1weighted imaging and slight tumor blush on angiography were detected. Such findings may indicate that part of the tumor has a rich blood flow $(2,5)$. In fact, histological examination showed increased numbers of vessels compared to normal cerebellar tissue. Of the six cases reported in elderly patients, four showed enhancement with contrast medium on MRI or tumor stain on angiography. These findings may indicate a tendency toward hypervascularity in the elderly.

In general, surgical excision is the only viable treatment approach (1-5, 7-11). Complete excision of the hypertrophied lesion is the treatment of choice, because regrowth or malignant transformation following subtotal resection of the lesion have been reported $(4,9)$. Many authors have recommended gross total removal in young adults, even in the absence of symptoms (11). However, complete excision is not always achievable because the lesion usually blends into normal cerebellar tissue and is thus difficult to distinguish from normal tissue $(2,5,7,10)$. In addition, extensive resection risks include neurological deficits such as cerebellar mutism (1). In fact, because we could not define the margins of the mass, partial resection was performed, although folia that were obviously widened compared to normal were seen.

In the elderly, surgical treatment should be chosen when patients are symptomatic. In fact, all reported patients were symptomatic and underwent partial resection to reduce mass effect. As a result, clinical symptoms improved without complication. Moreover, regrowth of the tumor did not occur in all patients. Partial resection to reduce mass effect can thus be chosen in the elderly, because the lesion is categorized as a World Health Organization grade I tumor. If the mass is accidentally found, a conservative strategy can be chosen with close follow-up examination.

In our case, the patient suffered from headache due to tonsillar herniation. Hence, partial resection to solve tonsillar herniation was performed and headache improved without complication. Thus, we recommend partial resection to decompress the fourth ventricle, the brain stem and the cerebellum in the elderly.

\section{CONCLUSION}

LDD is a rare entity with benign pathological findings. Several differences in the nature of the lesion are seen in the elderly, with tendencies toward a male predominance, hypervascularity, and low rates of association with $C D$ and regrowth after surgery. In symptomatic LDD in the elderly, to avoid surgical complication, we recommend partial resection to reduce mass effect. 


\section{REFERENCES}

1. Afshar-Oromieh $A$, Linhart $H$, Podlesek $D$, Schermpf $W$, Schackert G, Krex D: Postoperative cerebellar mutism in adult patients with Lhermitte-Duclos disease. Neurosurg Rev 33:401-408, 2010

2. Andres RH, Guzman R, Weis J, Brekenfeld C, Fandino J, Seiler RW: Lhermitte-Duclos disease with atypical vascularization-case report and review of the literature. Clin Neuropathol 28:83-90, 2009

3. Goto $Y$, Hashimoto N, Okita Y, Goto T, Rabo C, Hirayama H, Horikawa Y, Kinoshita M, Kagawa N, Yoshimine T: A surgically treated case of Lhermitte-Duclos disease with a precise natural history and high uptake of FDG on PET. J Neurooncol 97:445-450, 2010

4. Inoue T, Nishimura S, Hayashi N, Numagami $Y$, Kaimori M, Nishijima M: Ectopic recurrence of dysplastic gangliocytoma of the cerebellum (Lhermitte-Duclos disease): A case report. Brain Tumor Pathol 24:25-29, 2007

5. Ishizaki K, Daita G, Yonemasu Y, Kunimoto M, Miyokawa N: Hypervascularity in Lhermitte-Duclos disease-case report. Neurol Med Chir (Tokyo) 37:403-406, 1997
6. Moonis G, Ibrahim M, Melhem ER: Diffusion-weighted MRI in Lhermitte-Duclos disease: Report of two cases. Neuroradiology 46:351-354, 2004

7. Nakagawa T, Maeda M, Kato M, Terada N, Shimizu S, Morooka Y, Nakano H, Takeda K: A case of Lhermitte-Duclos disease presenting high FDG uptake on FDG-PET/CT. J Neurooncol 84:185-188, 2007

8. Nowak DA, Trost HA: Lhermitte-Duclos disease (dysplastic cerebellar gangliocytoma): A malformation, hamartoma or neoplasm? Acta Neurol Scand 105:137-145, 2002

9. Takei $H$, Dauser $R$, Su J, Chintagumpala $M$, Bhattacharjee MB, Jones J, Adesina AM: Anaplastic ganglioglioma arising from a Lhermitte-Duclos-like lesion. Case report. J Neurosurg 107:137-142, 2007

10. Yang MS, Kim CH, Cheong JH, Kim JM: Lhermitte-Duclos disease presenting with hydrocephalus. Acta Neurochir Suppl 113:161-165, 2012

11. Zou YH, Cao YQ, Yue ZJ, Liu JM: Unusual posterior fossa mass caused by Lhermitte-Duclos disease with no symptoms in adults. Br J Neurosurg 26:99-101, 2011 